\title{
Václav Jan Tomášek (1774-1850): A Versatile Lieder Composer? A Comparative Analysis of Selected Goethe Settings by Carl Friedrich Zelter, Václav Jan Tomášek and Johanna Kinkel
}

\author{
Anja Bunzel - Barbora Kubečková
}

\section{Introduction}

At the end of the eighteenth and during the nineteenth centuries, many composers were inspired by German literature, including poetry by Heinrich Heine (1797-1856), Friedrich von Schiller (1759-1805) and Johann Wolfgang von Goethe (1749-1832). ${ }^{21}$ Especially the vocal genres, more particularly the nineteenth-century Lied, feature poems by these renowned German poets. In his article Jan Václav Tomášek's Goethe Lieder, Kenneth DeLong argues that, although Heinrich Heine's poems were the ones set to music most, Goethe's poetry "provided the literary basis for a remarkable flowering of the lied that began during the final years of the eighteenth century and which lasted to the modern era". ${ }^{22}$ Goethe was well-known across the European lands and also a number of Bohemian composers set to music some of his poetry. ${ }^{23}$ Although such musicologists as Kenneth DeLong, Marie Tarantová, Theodora Straková, and Jan Smaczny have alluded to the

${ }_{21}$ Parts of this paper have been presented at the Annual Conference of the Society for Musicology in Ireland in June 2014. We wish to thank the SMI for the opportunity to present and discuss our findings with an international audience. Furthermore, we wish to thank our (past and current) supervisor Dr Lorraine Byrne Bodley for her ongoing support and inspiring criticism and Dr Patrick Devine for his advice and encouragement. Finally, Anja would like to extend her sincere gratitude to the Irish Research Council for their generous support of her research.

22 DeLong, Kenneth: Jan Václav Tomášek’s Goethe Lieder, Kosmas, 1988, iss. 7, p. 84. DeLong refers to Goethe's new expressive style by applying "freer verse forms, imaginative rhythms, [and] a new spontaneous freshness".

23 For example Václav Jan Tomášek (1774-1850), Václav J. Veit (1806-1864), Josef Antonín Štěpán (1726-1797), Bedřich Smetana (1824-1884), and Zdeněk Fibich (1850-1900). 
friendly relationship between Goethe and Tomášek in their writings, ${ }^{24}$ the actual nature of this acquaintanceship has not received a great deal of international acknowledgement and in-depth attention. ${ }^{25}$ Václav Jan Tomášek's relationship with Goethe was primarily based on an exchange of four letters from 1818-1820. ${ }^{26}$ When Tomášek met Goethe in 1822 for the first time, he introduced some of his Goethe settings to Goethe, who valued and praised Tomášek's Lieder. Goethe's fondness for Tomášek’s settings of his words is reflected in a statement by Counsellor Joseph S. Gruener (1780-1864), who, after a meeting with Goethe, resumes that:

At home, Goethe talked a lot about musical compositions, especially those of Zelter. [...] Then he talked about Tomasek's achievements and praised his artistic compositions. ${ }^{27}$

24 DeLong, K.: Jan Václav Tomášek’s Goethe Lieder, Kosmas, 1988, iss. 7, p. 71-90; Tarantová, Marie: Setkání skladatele V. J. Tomáška s J. W. Goethem, Od Dyleně, 1948, iss. 5, p. 57, iss. 6, p. 61-66. Unfortunately, we were not able to access this article; Straková, Theodora: Tomáškovy písně na Goethovy texty. Příspěvek k poznání vokální tvorby raného romantismu v našich zemích, Časopis Moravského muzea 40, 1955, p. 214-252; Smaczny, Jan: Goethe and the Czechs, in: Byrne Bodley, Lorraine (ed.), Goethe: Musical Poet, Musical Catalyst, Dublin: Press, 2004, p. 159-184.

25 There are two German-language publications dealing with Tomášek's encounters with Goethe: von Buquoy, Margarete: Begegnungen in Böhmen: Goethe, Buquoy, Tomaschek, Munich: Verlagshaus Sudetenland, 1987; and Urzidil, Johannes: Goethe in Böhmen, Vienna/ Leipzig: Hans Epstein, 1932.

${ }_{26}$ We wish to thank the Goethe-und Schiller-Archiv in Weimar and the Czech National Museum in Prague for providing us with photocopies of the following correspondence between Tomášek and Goethe: Tomášek's letter to Goethe from 29 June 1818, Goethe-und Schiller-Archiv, Weimar, Signature: GSA 28/79 B1. 477 and musical attachment: GSA 32/1027; Goethe’s letter to Tomášek 1 September 1818, Goethe-und Schiller-Archiv, Weimar, Signature: GSA 28/18 (concept); Tomášek’s letter to Goethe from June 1820 archived in the Czech National Museum Prague, Signature: G13684 (concept); Goethe's letter to Tomášek from 18 July 1820, Goethe-und Schiller-Archiv, Weimar (concept, original unknown).

27 Grüner cited after Gräf, Hans Gerhard: Goethe über seine Dichtungen, Darmstadt: Wissenschaftliche Buchgesellschaft, 1967, p. 459. "Zu Hause sprach dann Goethe viel von musikalischen Compositionen, besonders von jenen Zelters, [...] Dann sprach er über Tomascheks Verdienste und lobte dessen kunstreiche Compositionen.” Goethe's diary entry on 6 August 1822 confirms Gruener's words: "[In the morning] Capellmeister Tomášek from Prague. [...] 10:30 visited the advocate Frank, where Tomášek played, sang and brilliantly performed some of my songs. Till $6 \mathrm{pm}$, when the advocate Frank, Tomášek and the counsellor Gruener came to visit me; [...] the latter of whom stayed till late. [With Gruener we talked] About musical compositions, Tomášek's achievements and what I am wishing him.” (Goethe cited after Gräf, Hans Gerhard: Goethe über seine Dichtungen, Darmstadt: Wissenschaftliche Buchgesellschaft, 1967, p. 460. "[Morgens] Capellmeister Tomaschek von Prag [...]. Halb Eilf zu Gerichtsadvocate Frank, wo Tomaschek von meinen Liedern spielte, sang und glücklich vortrug. Für mich bis sechs Uhr, wo Gerichtsadvocat Frank, Tomaschek und Rath Grüner mich besuchten; [...] Letzterer blieb bis spät. Über musikalische Composition, Tomascheks Verdienste, und was ihm zu wünschen.” 
Perhaps Goethe complimented on Tomášek's compositional language, which combines Classical structural features and Romantic emotionality, as this reflects the poet's own aesthetic understanding of composition. ${ }^{28}$

Tomášek set to music forty-five of Goethe's poems. Forty-one songs are organised in nine books prevalently composed in Schubert's Liederjahr $1815 .{ }^{29}$ Although Tomášek's musical life and works have been subject to a few recent (and not so recent) publications, ${ }^{30}$ Tomášek's Goethe settings have been largely ignored by the musicological research canon. ${ }^{31}$ In 1955, Theodora Straková analysed each song in comparison to Schubert's Goethe

28 DeLong, K.: Jan Václav Tomášek’s Goethe Lieder, Kosmas, 1988, iss. 7, p. 72-73. For further details on Goethe's aesthetic understanding of the Lied see Kienzle, Ulrike: Goethe, Johann Wolfgang von, in: Musik in Geschichte und Gegenwart, Personenteil, 7th volume, 2nd edition, Kassel et al, 2002, col. 1192-1213. According to Kienzle, Goethe's aesthetic ideal was vocal music whereby Mozart took the primat. Therefore, Goethe must have appreciated strophic settings and regular phrasal patterns, which were used during the Classical period and which recur in all of the Lieder examined in this article. As a challenge to the composer, Kienzle points to Goethe's expectation that the melodic and instrumental parts of each strophe should correspond with the textual content of each stanza, a demand which addresses the challenge to reflect different Romantic emotions by means of multiple interpretative options in both voice and accompaniment as well as expressive instructions.

29 It is not known whether Tomášek composed all of his 41 Goethe settings in 1815 . However, considering Tomášek's first letter to Goethe from 29 June 1818, which included the first book of Tomášek’s Goethe settings, we can assume that all of his Goethe Lieder were written, compiled and at least partly published by July 1818. In this letter, Tomášek writes: "Only under these conditions am I taking the liberty to introduce to you my innermost desire, namely: to dedicate a separate book (including the Erlkönig, Der König in Thule and Der Fischer) to your name." Tomášek to Goethe on 29 June 1818, signature: GSA 28/79 B1. 477. "Nur in dieser Voraussetzung bin ich so frei, E. E. meinen sehnlichen Wunsch hier zu eröffnen, nämlich: zu einem Separathefte [den Erlkönig, den König in Thule, den Fischer enthaltend] Dero gefederten Namen vorzusetzen zu dürfen.” Much later (the exact date is not known), two poems were set for choir, Tischlied von Goethe für Tenor und Chor mit Begleitung des Pianoforte [Table Song by Goethe for Tenor and Choir with Piano Accompaniment] (op. 93) and Der Heilige Nepomuk (Saint Nepomuk) without opus number. Tomášek's fascination for Goethe's Faust culminated in two musical-dramatic settings: Gretchen am Spinnrade aus Goethes Faust für Gesang mit Begleitung des Orchesters [Gretchen at the Spinning Wheel from Goethe's Faust for Voice and Orchestra] op. 102, in which Tomášek sets Goethe's poem Meine Ruh' ist hin [My Peace is Gone]; and Scene mit Requiem aus Goethes Faust mit Begleitung des Orchesters [Requiem Scene from Goethe's Faust with Orchestra], op. 103.

30 Kabelková, Markéta: Václav Jan Tomášek (1774-1850) život a dílo (unpublished doctoral thesis, Karlova Univerzita Praha, 2012); Postler, Miroslav: Václav Jan Tomášek, Praha: St. Knihovna ČSR, 1960; Thompson, Verne Waldo: Jan Wenzel Tomaschek: His Predecessors, His Life, His Piano Works, Rochester/New York: University of Rochester, 1957; Tarantová, M.: V. J. Tomášek, Praha: Orbis, 1946; Václav Jan Tomášek, Vlastní životopis Václava Jana Tomáška, ed. by Zdeněk Němec, Praha: Topičova edice, 1941.

31 Although Kenneth DeLong pointed to the lack of musicological consideration of Tomášek's Goethe Lieder in 1988, only one relevant publication can be traced between 1988 and now: Smaczny, J.: Goethe and the Czechs, in: Byrne Bodley, Lorraine (ed.), Goethe: Musical Poet, Musical Catalyst, Dublin: Press, 2004. However, this publication does not include any analysis of Tomášek’s Goethe 
settings, an approach which revealed a great number of commonalities and similarities between Schubert's and Tomášek's compositional styles and which demonstrated Tomášek's underrated abilities as a Lieder composer. ${ }^{32}$ Two decades later, in 1977, Jan Panenka discussed Tomášek's Goethe settings in his unpublished diploma thesis Písňová tvorba Václava Jana Tomáška, which includes a limited analysis of Tomášek’s Goethe Lieder based on Straková's research. ${ }^{33}$ In 1988, Kenneth DeLong introduced Tomášek's Goethe songs to the English-speaking world. Besides a contextualisation of Tomášek’s compositions within the nineteenth-century Lieder discourse, his article provides a close reading of Tomášek's Schäfers Klagelied, Wandrers Nachtlied, An Linna, and Der Fischer. ${ }^{34}$

By comparing Tomášek's Lieder An den Mond [To the Moon] and Nachgefühl [Emotional Restrospect] with Carl Friedrich Zelter's and Johanna Kinkel's settings of the same words, this article ties in with the analytical examinations of our predecessors and will explore Tomášek's compositional language and his various stylistic directions. ${ }^{35}$ Firstly, a comparative analysis of Tomášek's Lied An den Mond will be undertaken in order to show some of Tomášek's compositional specialities. In a next step, this article will offer a close reading of Zelter's, Kinkel's and Tomášek's settings of Goethe's Nachgefühl, a methodological step which will emphasise the stylistic differences between the two chosen Lieder. Finally, this article will reflect on Václav Jan Tomášek's compositional versatility and its future challenges for the musicological research community.

Lieder but discusses a selection of Tomášek's Goethe settings as a whole in the context of the era; it also examines the relationship between Goethe and Tomášek on the basis of the composer's diary.

32 Straková, T.: Tomáškovy písně na Goethovy texty. Př́spěvek k poznání vokální tvorby raného romantismu v našich zemích, Časopis Moravského muzea 40, 1955, p. 218-219.

33 Panenka, J.: Písňová tvorba Václava Jana Tomáška (unpublished diploma thesis, Praha 1977).

34 DeLong, K.: Jan Václav Tomášek’s Goethe Lieder, Kosmas, 1988, iss. 7, p. 71-90.

35 One might wonder why the authors of this article chose Carl Friedrich Zelter's and Johanna Kinkel's settings for comparison. Considering the commonalities and differences between Tomášek, Zelter and Kinkel, a comparison between the three composers seemed especially fruitful in examining Tomášek’s compositional versatility. Like Tomášek, Zelter (1758-1832) knew Goethe in person although his acquaintanceship with Goethe was much closer and lasted longer than Tomášek's. (For further details on the relationship between Goethe and Zelter see Byrne Bodley, L.: Goethe and Zelter: Musical Dialogues, Aldershot: Ashgate, 2009). On the contrary, Johanna Kinkel (1810-1858) did not know Goethe in person at all; her musical acquaintanceship with Goethe's poetry, however, is worth noting as her Goethe settings were reviewed by such renowned nineteenth-century reviewers as Ludwig Rellstab (Iris im Gebiete der Tonkunst 2, 12 January 1838, p. 5-6), Gottfried Wilhelm Fink (Allgemeine Musikalische Zeitung 32, August 1838, p. 524-525), and Oswald Lorenz (Neue Zeitschrift für Musik 20, 9 March 1838, p. 77-78). Additionally, the differences in relation to gender and time seemed attractive for this comparison, an aspect which will be examined again at the end of this article. 


\section{Václav Jan Tomášek's An den Mond: on the co-existence of folk-like simplicity and chromatic allusions}

In the poem An den Mond ${ }^{36}$ the "lyrical I" wanders through an inspiring landscape and reflects on various symbols of nature that capture his/ her catharsis from the sorrow of love. ${ }^{37}$ At the beginning of the poem, the moonlight enables the protagonist to succeed in his/ her search for inner peace. The river, which is referred to in stanzas four and six accompanies the poet's lamentation and portrays the passing of time in human life. Nature and music are united and both offer solace from heartache (stanza six). If the winter recalls the past, spring awakens the desire for new life (stanza seven). As Lorraine Byrne asserts in her interpretation of this poem, "the opening image of the moon links with the closing image of the labyrinth, for in both verses Goethe suggests a transition from darkness to light. [...] Through nature, which is experienced in love, [the protagonist] finds inner peace." 38

36 Tomášek published An den Mond in 1815, the Liederjahr in which he set a large number of Goethe's poems and, coincidentally, the same year in which Schubert composed his first (and more popular) version of the same words. The song is included in Tomášek's fourth book, Gedichte von Goethe. It takes the fourth place in this book alongside the settings Schäfers Klagelied [Shepherd's Lament], Selbstbetrug [Self-deception], Erster Verlust [First Loss], and Hochzeitslied [Wedding Song]. At this time Tomášek was in Count Buquoy's services as a music teacher and composer. It is not known why Tomášek chose to set these particular poems; however, the long-lasting idea to do so is claimed in his autobiography, "Selbstbiographie", Libussa, 1847, iss. 6, p. 411-441, 438.

37 As Lorraine Byrne points out, Goethe's poem An den Mond was inspired by Heinrich Leopold Wagner's musical parody of the same title published in the Almanach der deutschen Musen in 1776. Goethe wrote this parody during the winter $1777 / 1778$ and sent his version of the lyrics with original music to Charlotte von Stein (1742-1827). Ten years later, during Goethe's Italian journey, a grieving Charlotte parodied Goethe's lyrics and sent it back to the poet. The final version of his poem includes Charlotte's verses and was published in his Schriften in 1789. (Byrne, L.: Schubert's Goethe Settings, Ashgate, 2003, p. 113-114)

38 Ibid., p. 115. 
Table 1: Lyrics, Translation and Formal Structure of Carl Friedrich Zelter's, Václav Jan Tomášek's and Johanna Kinkel's An den Mond ${ }^{39}$

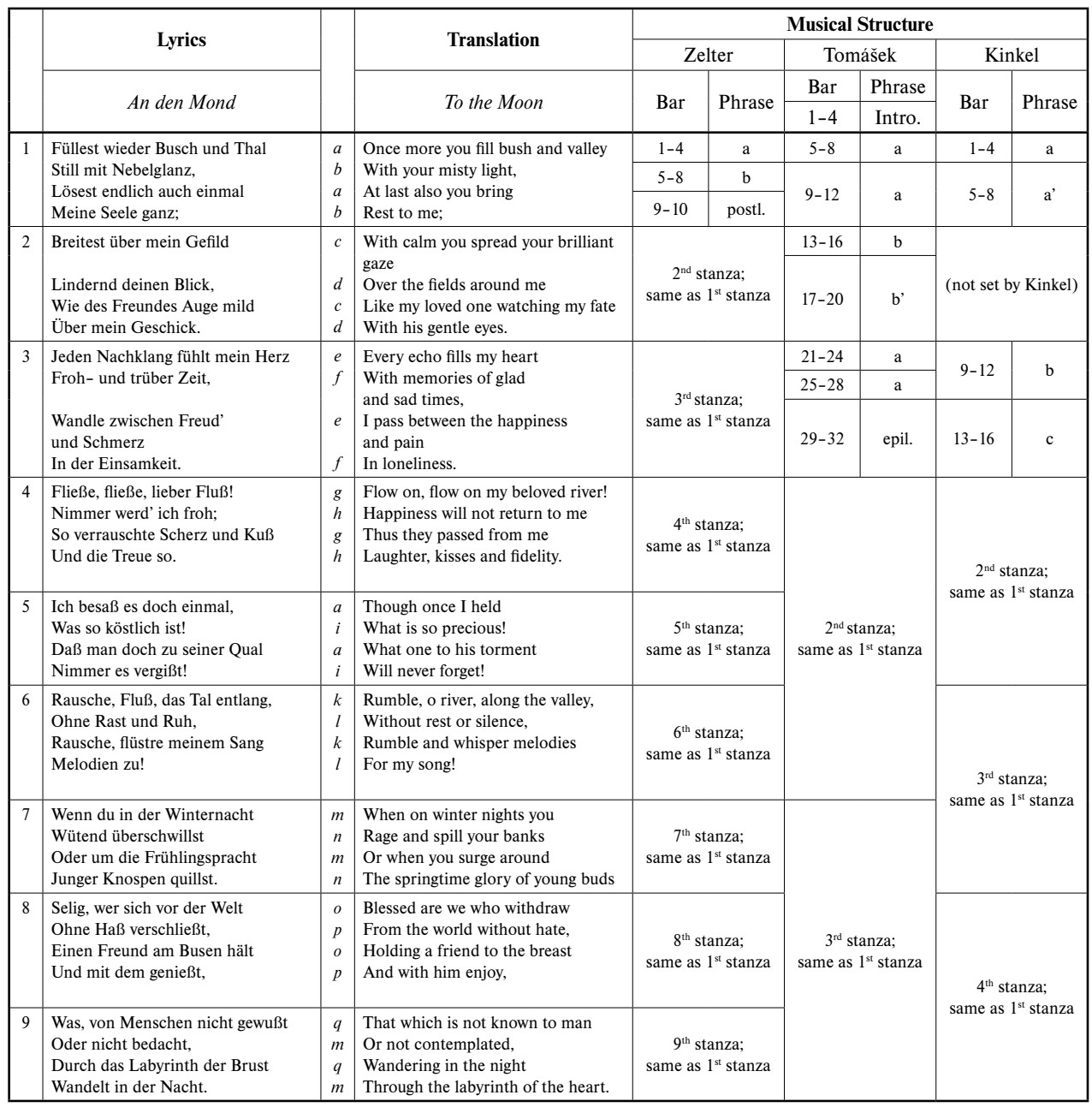

The difficulty in setting Goethe's An den Mond, which, according to Lorraine Byrne, is widely known on account of "the absolute musicality of the verses", ${ }^{40}$ is reflected by the manifold ways in which various composers approached and interpreted this poem. ${ }^{41}$ As

39 Translation by Scott Horton, 〈http://harpers.org/blog/2010/02/goetheschubert-_an-den-mond_/> [accessed 28 April 2014].

40 Byrne, L.: Schubert's Goethe Settings, Aldershot: Ashgate, 2003, p. 116.

${ }^{41}$ Other composers who set to music Goethe's poem An den Mond include: Karl Sigmund Freiherr von Seckendorff (1744-1785), Johann Friedrich Reichardt (1752-1814), Friedrich Heinrich Himmel 
is shown in table 1, Zelter, Tomášek and Kinkel chose three different ways of organising the poetry formally although all three composers stick to the original poetic form of four lines per stanza. While the poetic and musical stanzas correspond with each other in Zelter's setting (published in 1812) Tomášek unites three poetic stanzas in one musical strophe. ${ }^{42}$ By comparison, Kinkel in her version (which was published in 1838) links only two poetic stanzas in each musical strophe. ${ }^{43}$ All three composers respond to the poem's continuous trochaic metre and the regular strophic structure by means of even metres and four-bar phrases, each of which include two poetic lines.

The melodic and rhythmic simplicity in Tomášek's setting alludes to a folk song. Each A part is characterised by a stepwise melodic ascent. This melodic figure is emphasised by a latent second voice in the piano right hand (Ex. 1a).

Ex. 1a: Recurring melodic figure with latent second voice in piano part in Tomášek's An den Mond (bars 5-6) ${ }^{44}$

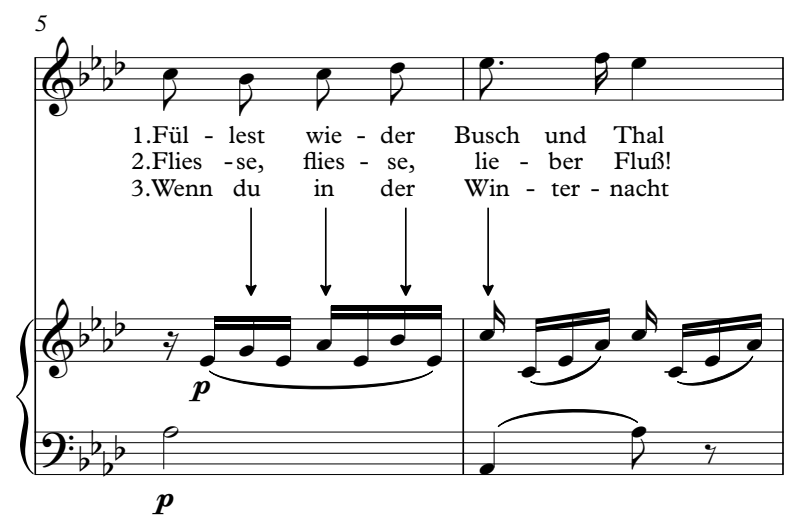

Interestingly, Carl Friedrich Zelter's setting, which was produced three years before Tomášek's, includes the exact same feature over the second rhyming couplet of each stanza (Ex. 1b).

(1765-1814), Andreas Jakob Romberg (1767-1821), Moritz Hauptmann (1792-1868), Ferdinand von Hiller (1811-1885), Bernhard Klein (1793-1832), Franz Schubert (1797-1828), Wilhelmine Schwertzell, Georg Vierling (1820-1901), Leopold Damrosch (1832-1885), Christian Friedrich Grimmer (1798-1850), Felix Draeseke (1835-1913), Arnold Mendelssohn (1855-1933), Zdeněk Fibich (1850-1900), and Anton Urspruch (1850-1907).

42 Cf. Straková, T.: Tomáškovy písně na Goethovy texty. Př́spěvek k poznání vokální tvorby raného romantismu v našich zemích, Časopis Moravského muzea 40, 1955, p. 233.

${ }_{43}$ Kinkel does not set the second stanza of Goethe's poem.

${ }_{44}$ All excerpts of Tomášek's An den Mond have been typeset from Tomaschek, Wenzel Johann: Gedichte von Goethe mit Begleitung des Piano-Forte, book 4 (self-published, c1818). 
Ex. 1b: Melodic figure with latent second voice in piano in Zelter's An den Mond (bars 4-6) $)^{45}$

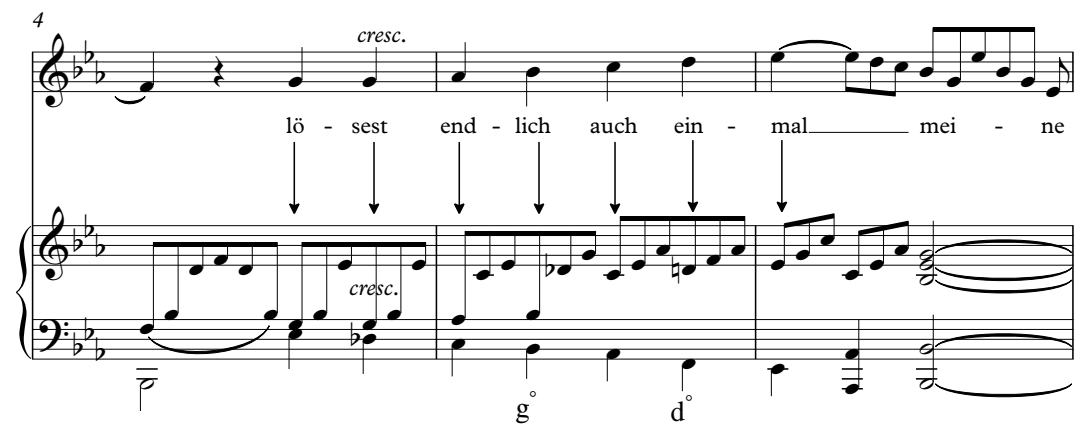

Similarly to Tomášek, Zelter's Lied also bears folk-like characteristics. The triplets in the right hand piano allude to a calming lullaby; however, the melodic variety in the piano accompaniment, which is achieved by dividing each six-crochet unit into two sections of three crochets each, corresponds directly with the rising tension of the poem (third beat of bar 4, Ex. 1b). While Kinkel's piano part also takes on a purely accompanying function, it is much more challenging due to its multi-note chords; however, as regards melodic direction, it does not correspond with the vocal part (Ex. 1c, bars 1-4).

Ex. 1c: Melodic independence between vocal part and piano in Kinkel's An den Mond $(\text { bars } 1-4)^{46}$

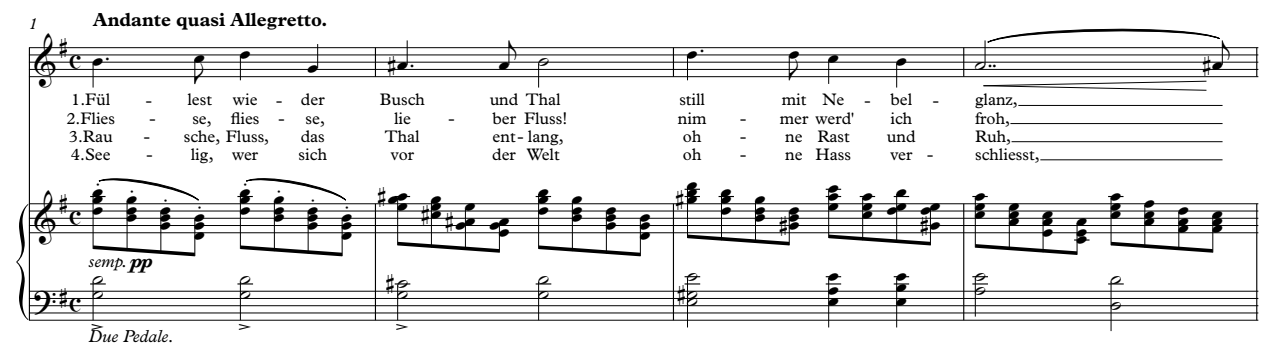

45 All excerpts of Zelter's An den Mond have been typeset from Friedländer, Max (ed.): Gedichte von Goethe in Compositionen seiner Zeitgenossen, Weimar: Goethe-Gesellschaft, 1896, p. 58.

${ }^{46}$ All excerpts of Kinkel's An den Mond have been typeset from Mathieux [Kinkel], Johanna: Sechs Lieder für eine Singstimme mit Begleitung des Pianoforte: Op. 7, Berlin 1838, p. 12-13. We would like to thank the Universitäts- und Landesbibliothek Bonn for their generous permission to publish excerpts of scores held in their archives. Both scores of Kinkel's Lieder examined in this article are available in the ULB. 
In terms of expression, Zelter's, Tomášek's and Kinkel's settings reflect the progression of compositional style and popularity from the late eighteenth to the mid-nineteenth centuries. While Zelter hardly uses any expressive instructions (he overwrites his setting "Ruhig" [calm], applies a crescendo over the second rhyming couplet of each strophe, and instructs the pianist to play the final two bars of each strophe softly), Tomášek uses a greater number of expressive means. Besides his tempo marking ("Andantino") and numerous piano instructions, he employs a few crescendos and uses a forte expression over the words "Freud und Schmerz" (happiness and pain; first stanza), "meinem Sang [Melodien zu]" ([whisper melodies] for my song; second stanza) and "Labyrinth der Brust" (labyrinth of the heart; third stanza). Like Zelter and Tomášek, Kinkel sets her Lied in a calm and peaceful tempo. However, Kinkel's tempo instruction Andante quasi Allegretto points to the rather challenging piano accompaniment, which, alongside a few dynamic changes, is characterised by a great number of tempo changes and arpeggios.

In a similar way, the harmonic designs of the three compared settings increase their complexity in correspondence with their chronological order. Zelter's Lied is based on the tonic key (E flat major), its dominant (B flat major) and subdominant (A flat major). The only harmonic exception is made in bar six, when the melodic figure introduced above is harmonized with two diminished triads over g and d, respectively (bar 5, Ex. 1b). Also Kinkel and Tomášek use diminished chords; however, both of them apply more complex harmonic progressions using the diminished seventh chord which allows for more remote modulations. While Tomášek does not apply this harmonic feature until the piano postlude of each musical strophe (Ex. 2), Kinkel's setting includes diminished seventh chords at three different places (table 2).

Ex. 2: Chromatic piano epilogue of Tomášek’s An den Mond, (bars 28-34) ${ }^{47}$

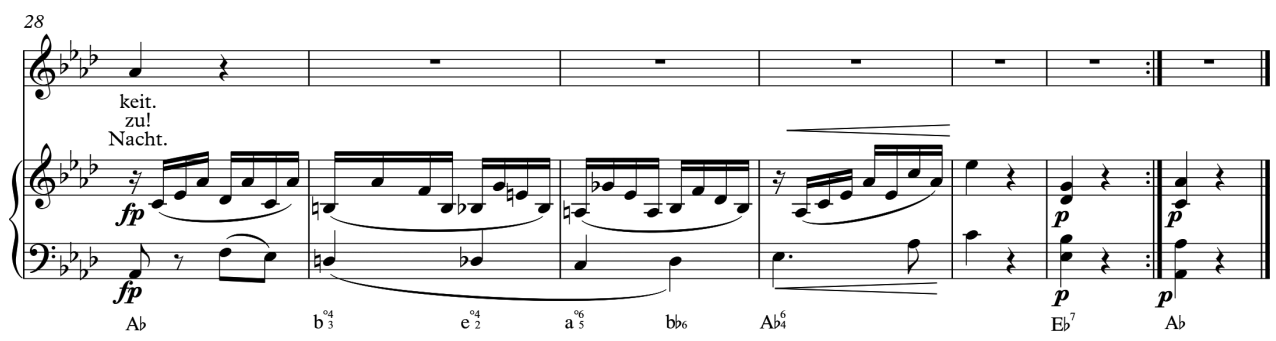

${ }^{47}$ Capitalised letters indicate major quality of a chord; lower case letters indicate minor quality of a chord. 
Table 2: Harmonic design of Kinkel's An den Mond ${ }^{48}$

\begin{tabular}{|c|c|c|c|c|c|c|c|c|c|c|c|c|c|c|c|c|}
\hline Bar & 1 & 2 & 3 & 4 & 5 & 6 & 7 & 8 & 9 & 10 & 11 & 12 & 13 & 14 & 15 & 16 \\
\hline Key & $G$ & $a \#^{07}-G$ & $E^{7}$ & $a-D^{7}$ & G & 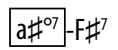 & $B-D^{7}$ & G & $G-g \#^{\circ 7}$ & $\left(\#^{7}-\mathrm{f} \#\right.$ & $\mathrm{F}^{7}-\mathrm{A}-\mathrm{E}^{7}$ & $A-D$ & G & $G^{7}-c$ & $G-D^{7}$ & $G$ \\
\hline
\end{tabular}

It is striking that both Zelter and Tomášek support the phrasal regularity of their settings by means of harmony, whereupon Tomášek applies a more varied harmonic framework including mediantic relationships in the B part of each strophe (bars 13-20, table 3). Suggesting a temporary withdrawal from the initial tonic key A flat major, each B part first introduces the relative minor key F minor (bars 13-14) and then touches on the upper mediant c minor (bar 18); in a next step, the harmonic progression is led back to the dominant E flat major and the tonic key A flat major in the A part (bars 21ff) tying in with the preceding tonal meander. An additional harmonic modification appears when the A part returns in bar 21: here, by playing with the tonal relationship between the dominant key and its relative minor (which is the mediant of the tonic), the repeated A part begins with the Janus-faced notes e flat and c (first beat, bar 21). It is not until the fourth beat of this bar (when the note d flat sounds) that the tonic key of A flat major is established by means of its dominant seventh chord (E flat major seventh).

Table 3: Harmonic design of the B part in Tomášek’s An den Mond

\begin{tabular}{|c|c|c|c|c|c|c|c|c|c|c|}
\hline \multirow{2}{*}{ Bar } & \multirow{2}{*}{12} & \multicolumn{8}{|c|}{ B } & \multirow{2}{*}{21} \\
\hline & & 13 & 14 & 15 & 16 & 17 & 18 & 19 & 20 & \\
\hline Key & $A_{b}$ & $E_{b}-C^{7}$ & $f$ & $f-C^{7}$ & $f$ & $G^{7}$ & c & $c-G^{7}$ & c & $c / E_{b}{ }^{7}$ \\
\hline
\end{tabular}

While Tomášek's setting is based majorly on mediant relations, Kinkel's harmonic progression of An den Mond, which does not correspond with the regular four-bar phrasal pattern suggested by the melodic layout of the song, seems more progressive. In his review in the Neue Zeitschrift für Musik, Oswald Lorenz regrets the unusual "tonal offset to A major" (in bar 12) and the naïve return to $G$ major (in bar 13 ) in this Lied. ${ }^{49}$ The vocal line in bar 13 suggests a parallelism to bar four, so the listener would - as an analogy to bar four -

48 The chords highlighted in boxes are diminished seventh chords.

49 Neue Zeitschrift für Musik 20, 1838, p. 77-78. "An den Mond von Goethe hat dagegen ein recht freundliches und gewinnendes Ansehn und wird sich namentlich viele Freundinnen erwerben. An der Ausweichung aber nach A-Dur, bei der das es (statt dis) sich so furchtlos unter die vielen Kreuze hineingewagt hat, und an der naiven Rückkehr nach G-Dur ist, wie an der zarten Haltung des ganzen Liedes vor allem die weibliche Hand zu erkennen.” 
expect an A minor chord rather than an A major chord here. However, considering the seemingly more sedate textual content delivered in bars 11-12, the offset to A major as opposed to A minor makes sense. Regardless of the reviewer's gender-biased criticism of the simple return to $\mathrm{G}$ major, ${ }^{50}$ Kinkel proves her tonal variety in the preceding bars, in which she applies a dimished seventh chord (bar 9) in order to create a harmonic state of uncertainty in the following bars. Bar 10 touches on a completely new tonal thought ( $\mathrm{C}$ sharp major and $\mathrm{F}$ sharp minor), followed by a remote progression ( $\mathrm{F}$ major seven A major) in bar 11. Figuratively, this tonal meander, which is of a much more complex and remote nature than the respective modulating part B in Tomášek's setting, might allude to the lack of knowledge referred to in the corresponding line of the final verse: "Was vom Menschen nicht gewußt, oder nicht bedacht" (That which is not known to man or not contemplated). Furthermore, it portrays the lyrical I's ramble "zwischen Freud und Schmerz" (between happiness and pain, first stanza) and the "Labyrinth der Brust" (labyrinth of the heart, last stanza).

Although, melodically Tomášek's setting does not incorporate a particularly strong climax, Tomášek emphasises the key words in the last two lines of each stanza by means of varied harmony (Ex. 3).

Ex. 3: Harmonic emphasis on keywords in Tomášek's An den Mond (bars 25-28)

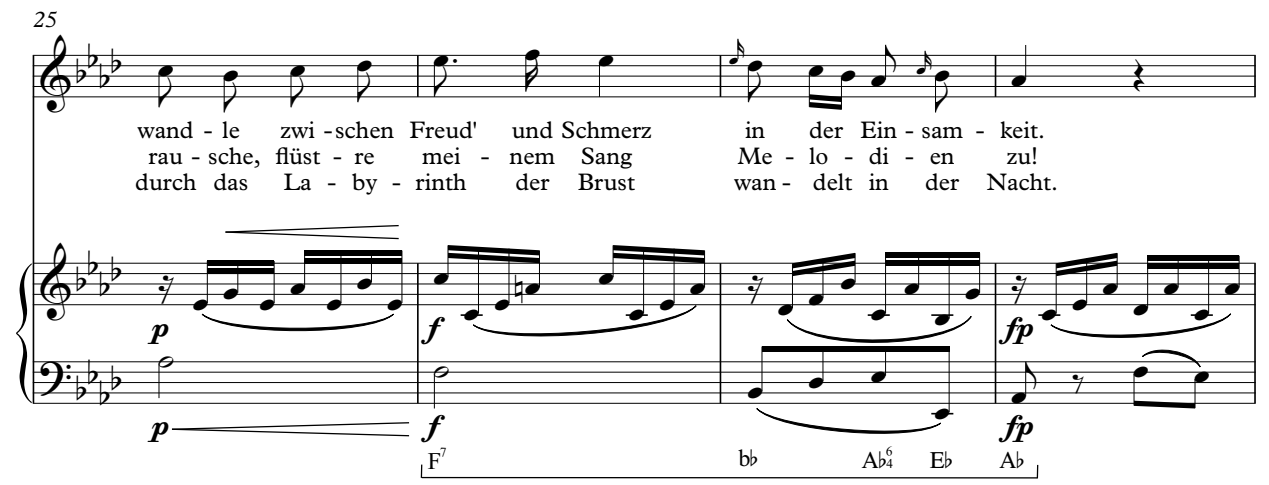

Besides the forte dynamics, Tomášek introduces the key of B flat minor in order to underscore the sadness and loneliness portrayed in the corresponding verses. Tomášek illustrates the protagonist's wandering through the labyrinth of the heart with a chromatic piano epilogue harmonised with a falling series of consecutive diminished seventh chords

50 Lorenz seemingly criticises that Kinkel treats the double dominant A major as a substitution of the subdominant and concludes to $\mathrm{G}$ major via the dominant D major. In his review, he states that the return to $\mathrm{G}$ major and the soft setting in general revealed the female authorship of this Lied. For details on the harmonic progression of Kinkel's An den Mond see table 2. 
in bars 29-30, before concluding in the initial key of A flat major which connects to the musical introduction and the opening symbol of the moon (Ex. 2).

\section{Václav Jan Tomášek's Nachgefühl: on harmonic complexity and rhythmic variety}

Bearing in mind the rather less elaborate compositional complexity in Tomášek's Goethe setting An den Mond, let us now turn to the Lied Nachgefühl, with which Tomášek engaged musically at about the same time as An den Mond (1815-1818). ${ }^{51}$ Goethe wrote this poem in 1797 and entitled it "Erinnerung" (Memory) when it was first published. ${ }^{52}$ It is a love song in which feelings are released while remembering the past. Only by recalling the female name Doris in the last line, the poem reveals its full meaning. In his diary, Tomášek mentions the Lied Nachgefühl as one of the works he played to Goethe during their first meeting in Cheb (Eger) in 1822..$^{53}$ Although some fragments of Goethe's reaction to Tomášek's settings are bequeathed, his opinion about this song is not known.

In a similar way to An den Mond, all three composers stick to the traditional melodic four-bar phrasal pattern, whereby each musical phrase equals two poetic lines. Tomášek and Kinkel choose a 4/4 metre in correspondence with the trochaic metre of the poem; Zelter uses a 3/8 metre, but the melodic accents and the harmonic rhythm clearly support the even metre of the poem. In terms of formal design, Kinkel's Lied Nachgefühl is characterised by a very simple strophic formal structure, which corresponds with a straightforward harmonic pattern centring on the tonic key E major and its dominant B major. By comparison, both Zelter's and Tomášek's settings of the same words, both of which are noted as through-composed songs, are far more complex. As indicated in table 4, the two outer sections in Zelter's three-part setting (A and A', which include phrases a and b, and a' and b', respectively) feature similar compositional traits while Tomášek sets the three poetic stanzas to three totally different musical strophes (ABC).

${ }^{51}$ Nachgefühl is included in the first book of Tomášek's Goethe settings (op. 53, no. 4) alongside the Lieder Heidenröslein (Wild Rose), Nähe des Geliebten (Proximity of the Beloved), Mailied (May Song); Trost in Tränen (Solace in Tears), and Wer kauft Liebesgötter? (Who will buy these cupids?).

${ }^{52}$ Straková, T.: Tomáškovy písně na Goethovy texty. Př́spěvek k poznání vokální tvorby raného romantismu v našich zemích, Casopis Moravského muzea 40, 1955, p. 223.

53 Tomaschek, W. J.: Selbstbiographie, Libussa, 1850, iss. 9, p. 331. 
Table 4: Lyrics, Translation and Formal Structure of Carl Friedrich Zelter's, Václav Jan Tomášek's and Johanna Kinkel's Nachgefühl

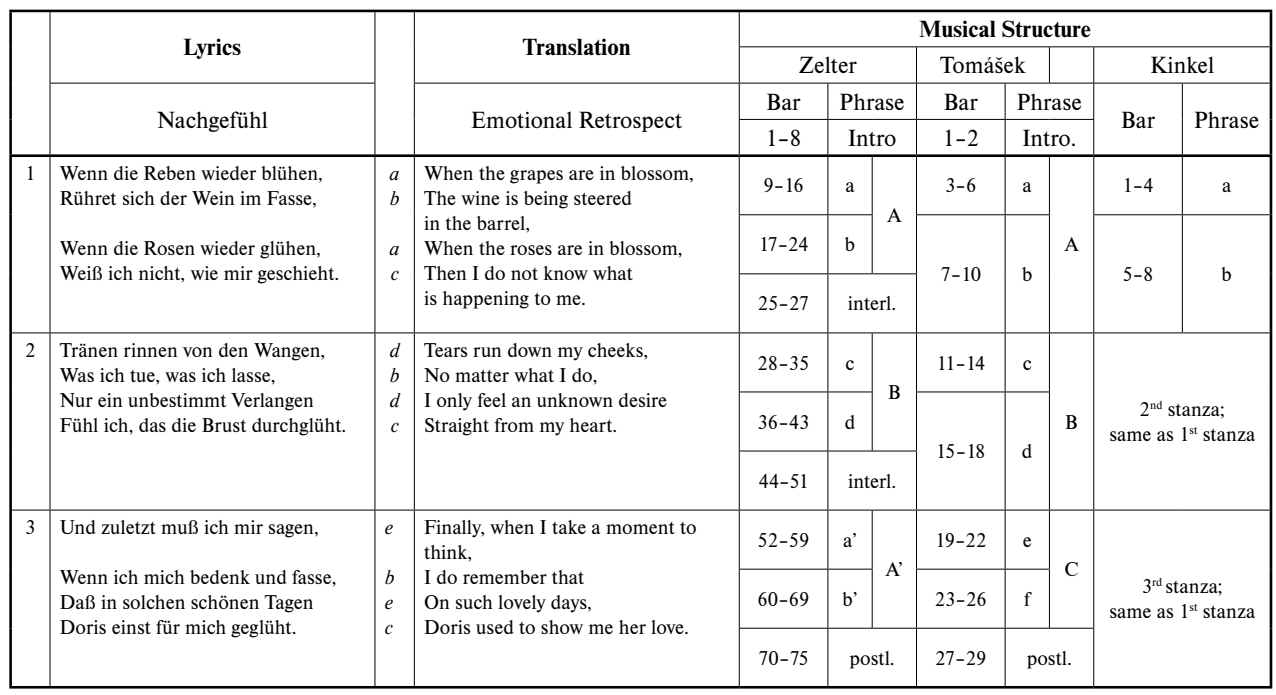

Both Zelter and Tomášek use a piano introduction as well as a piano postlude in order to establish the tonic key. However, Zelter's piano introduction and his postlude are considerably longer than Tomášek's and he also includes piano interludes between the individual vocal sections, which grant the Lied a more artistic (and pianistic) touch. Interestingly, Tomášek, like in An den Mond, employs a chromatic bass line in his piano postlude, which includes a half-diminished seventh chord over a; a diminished seventh chord over b; a German augmented Sixth chord; and a dense interplay with mediantic relationships (Ex. 4). Harmonically, this postlude is much more complex than the postlude of Tomášek's Lied An den Mond.

Ex. 4: Piano postlude in Tomášek’s Nachgefühl (bars 26-29) $)^{54}$

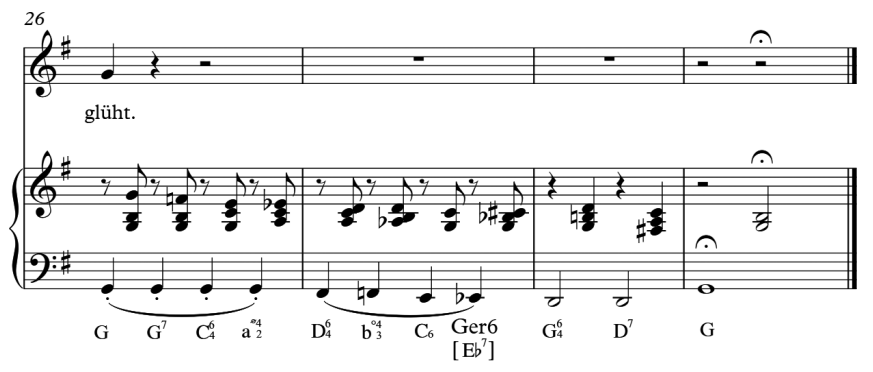

${ }_{54}$ All excerpts of Tomášek's Nachgefühl have been typeset from Tomaschek, W. J. Gedichte von Goethe für den Gesang mit Begleitung des Piano-Forte, Op. 53 (Münster, reprint 2003), p. 9-10. 
Unlike in An den Mond, Tomášek also employs a great deal of modulation and varied harmony within the vocal parts (Table 5).

Table 5: Harmonic design of Tomášek’s Nachgefühl

\begin{tabular}{|c|c|c|c|c|c|c|c|c|c|c|c|c|c|c|c|}
\hline Bar & 1 & 2 & $3-4$ & 5 & $6-7$ & 8 & 9 & 10 & 11 & 12 & 13 & 14 & 15 & $16-17$ & 18 \\
\hline Key & $G$ & $D$ & $G-D$ & $G-A^{7}$ & $D-E^{7}$ & $a$ & $G-a \#^{07}-G-D$ & $G-e$ & $B-E-B$ & $e$ & $C-c$ & $D^{7}$ & $G-C \#^{0}$ & $F \#^{7}-b-F \#$ & $b$ \\
\hline \multicolumn{10}{|c|}{$1^{\text {st }}$ stanza } & \multicolumn{7}{c|}{$2^{\text {nd }}$ stanza } \\
\hline
\end{tabular}

\begin{tabular}{|c|c|c|c|c|c|c|c|c|c|c|}
\hline 19 & 20 & 21 & 22 & 23 & 24 & 25 & 26 & 27 & 28 & 29 \\
\hline$E^{7}-\mathrm{e}$ & $\mathrm{a}$ & $\mathrm{b}^{\circ}-\mathrm{a}-\mathrm{E}$ & $\mathrm{a}$ & $\mathrm{D}^{7}-\mathrm{G}$ & $\mathrm{a}-\mathrm{A}-\mathrm{D}^{7}$ & $\mathrm{G}-\mathrm{a}-\mathrm{D}^{7}$ & $\mathrm{G}-\mathrm{C}$ & ${\mathrm{D}-\mathrm{b}^{07}-\mathrm{C}-\mathrm{Ger} 6}^{-} \mathrm{G}-\mathrm{D}^{7}$ & $\mathrm{G}$ \\
\hline \multicolumn{3}{|c|}{$3^{\text {rd }} \operatorname{stanza}$} & \multicolumn{3}{c|}{ postlude } \\
\hline
\end{tabular}

While, in Tomášek's Lied, the tonic key (G major) is established in the first stanza, the entire second stanza is made up of a modulation which stretches into the third stanza. It is not until the second phrase of the third stanza (bars 23ff.) that the initial tonic key is re-established. This dense harmonic language including unexpected harmonic turns and remote chords might reflect the "unbestimmt Verlangen" (unknown desire) voiced by the lyrical protagonist in the corresponding verse. In a similar way to Tomášek, Zelter applies modulation in the middle section of his Lied (Table 6).

Table 6: Harmonic design of Zelter's Nachgefühl

\begin{tabular}{|c|c|c|c|c|c|c|c|c|c|c|c|c|c|c|c|c|c|}
\hline Bar & $1-8$ & $9-16$ & $17-20$ & $21-24$ & $25-27$ & $28-29$ & 30 & $31-34$ & 35 & 36 & 37 & 38 & 39 & 40 & 41 & 42 & 43 \\
\hline Key & $G$ & $G$ & $B-e$ & $A^{7}-D$ & $D-D^{7}-G$ & $D^{7}$ & $g$ & $D^{7}$ & $g$ & $G^{7}$ & $c$ & $e^{07}$ & $D^{7}$ & $g$ & $B^{7}-e$ & $A$ & $D^{7}$ \\
\hline & prel. & \multicolumn{10}{|c|}{$1^{\text {st }}$ stanza } & interl. & \multicolumn{10}{|c|}{$2^{\text {nd }}$ stanza } \\
\hline
\end{tabular}

\begin{tabular}{|l|c|c|c|c|c|c|c|c|c|c|c|c|}
\hline $44-51$ & $52-55$ & $56-59$ & 60 & 61 & 62 & 63 & 64 & $65-66$ & 67 & 68 & 69 & $70-75$ \\
\hline$g-D-G$ & $G-D$ & $G^{7}-C-G-D$ & $B$ & e & $A$ & $D^{7}$ & $G$ & $C$ & $G$ & $D^{7}$ & $G$ & $G$ \\
\hline interl. & \multicolumn{10}{|c|}{$3^{\text {rd }}$ stanza } & postl. \\
\hline
\end{tabular}


In addition to a descending circle of fifths progression in the first stanza (bars 17-24), Zelter employs an interplay between the tonic key $\mathrm{G}$ major and $\mathrm{g}$ minor, which is especially seen in the second piano interlude (bars 44-51). Interestingly, Zelter, like Tomášek, emphasises the words "unbestimmt Verlangen" (unknown desire) by means of Janus-faced harmony as he applies a diminished seventh chord at the corresponding bar (bar 38). Besides the complex harmonic pattern of Nachgefühl, another remarkable coincidence links Tomášek with Zelter, who was the first composer to set Goethe's poem Äolsharfen in 1829. Goethe had written the words of this poem into Tomášek's memorial album when they met briefly in $1822 .{ }^{55}$ However, Tomášek himself never set to music these words of Goethe's. ${ }^{56}$

As regards the melodic progression of Nachgefühl, both Zelter's and Tomášek's settings are characterised by a great deal of melodic decoration and embellishment. In addition to this, Zelter's variation in the third musical stanza (A') is reached by a prolonged motif over the word "einst" (once; bars 65-67), which emphasises the retrospect approach to the love gone by. Neither Kinkel nor Tomášek stress this aspect to the same extent. Comparing the three settings, Kinkel's melodic line strikes on account of its contrast between the individual musical phrases (Ex. 5). Furthermore, Kinkel's setting includes a distinct melodic climax (bar 6), which stresses the words "glühen" (blossom; first stanza), "Verlangen" (desire; second stanza) and "schönen Tagen" (lovely days; third stanza). Kinkel clearly aims to stress the positive memories of the "lyrical I's" beloved rather than the fact that the love is over.

In Tomášek's setting, the lack of a high-contrast melodic line is balanced by an interesting rhythmical pattern of quaver chords in the left hand alternating with quaver rests appearing in the piano right hand, which, supported by an alla breve metre, alludes to such Czech folk-like elements as the polka. The legato bass line supports the harmony. All three composers are rather modest with dynamic expressions: Zelter does not include any such means and Kinkel only instructs the performer to play and sing the entire piece softly (piano); she employs a crescendo at the beginning of phrase b. Tomášek's Lied is also set in piano and includes a crescendo; however, this occurs over the words "Thränen rinnen von

55 Straková, T.: Tomáškovy písně na Goethovy texty. Př́spěvek k poznání vokální tvorby raného romantismu v našich zemích, Časopis Moravského muzea 40, 1955, p. 218.

56 During Tomášek's brief meeting with Goethe in 1822, Goethe, at Tomášek's request, wrote into the composer's memorial album a commemoration in the form of the first two verses from what would later be known as Äolsharfen, released in 1827 as a part of the Trilogie der Leidenschaft. (Released in Gedichte. Ausgabe letzter Hand, 1827) The poet titled the poem for Tomášek's memorial album Liebe Schmerzlicher Zwie-Gesang, unmittelbar nach dem Scheiden (Lovelorn Duet, Sung After Parting). This poem was written during Goethe's infatuation with Ulrike von Levetzow immediately after their farewell in the summer of 1822. Goethe wrote the poem on his way from Mariensbad to Eger. He gave these lines to Tomášek saying: "I created something diplomatic in memory of our encounter, I will be happy to know that you will remember it when you look at these lines." ("Da habe ich Ihnen etwas Diplomatisches zur Erinnerung an unser Zusammentreffen gemacht; es soll mich freuen, wenn Sie beim Anblick dieser Zeilen sich dessen erinnern”, in Tomaschek, W. J.: Selbstbiographie, Libussa, 1850, iss. 9, p. 328-332). 
den Wangen" (Tears run down my cheeks), which Tomášek might have considered an important line. This is also recognisable in the melodic progression of this line (bars 11-12, ex. 5). Here, the descending melody corresponds directly with the textual content of the corresponding line. Furthermore, Tomášek, on the words "Fühl ich, das die Brust durchglüht" (Straight from my heart), prolongs the dotted quaver pattern initially established in the vocal line, which results in a steady crotchet pattern in order to stress the "lyrical I's" desire for love. In the last stanza, where this desire is finally unfolded and the "lyrical I's" lost love is given a name, the vocal line is doubled in the upper notes of the piano right hand (bars 15-18), an effect which stresses the protagonist's strong feelings about the love gone by. The beloved's name, Doris, is portrayed by a linear ascent forming a tritone (g\#-a-b-c-d in bars 24-25), which pinpoints the lyrical protagonist's sorrowful reminiscence.

Ex. 5: Melodic lines of Kinkel's, Tomášek's and Zelters Nachgefühl $l^{57}$
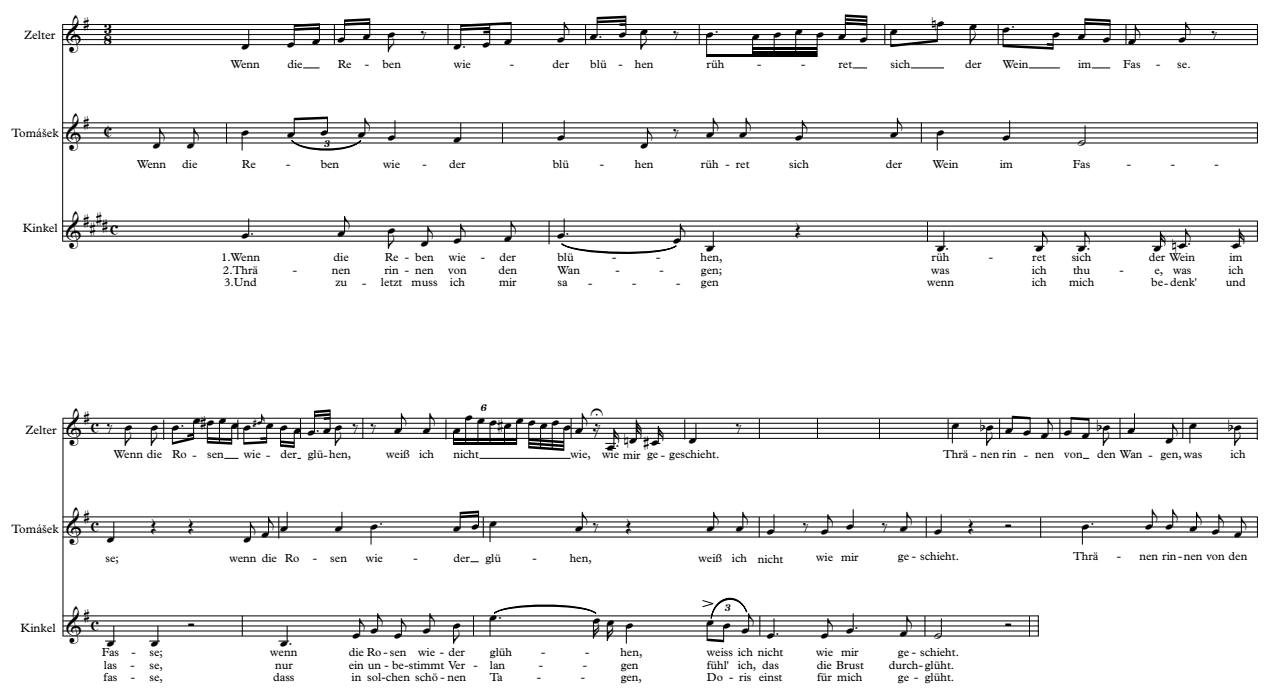

${ }_{57}$ Excerpt from Johanna Kinkel's Nachgefühl has been typeset from Mathieux [Kinkel], J. Sechs Lieder für eine Singstimme mit Begleitung des Pianoforte: Op. 10, Berlin 1839, p. 3; excerpt from Carl Friedrich Zelter's Nachgefühl has been typeset from Zelter, C. F. Neue Liedersammlung, Zürich/ Berlin 1821 , no pagination. 

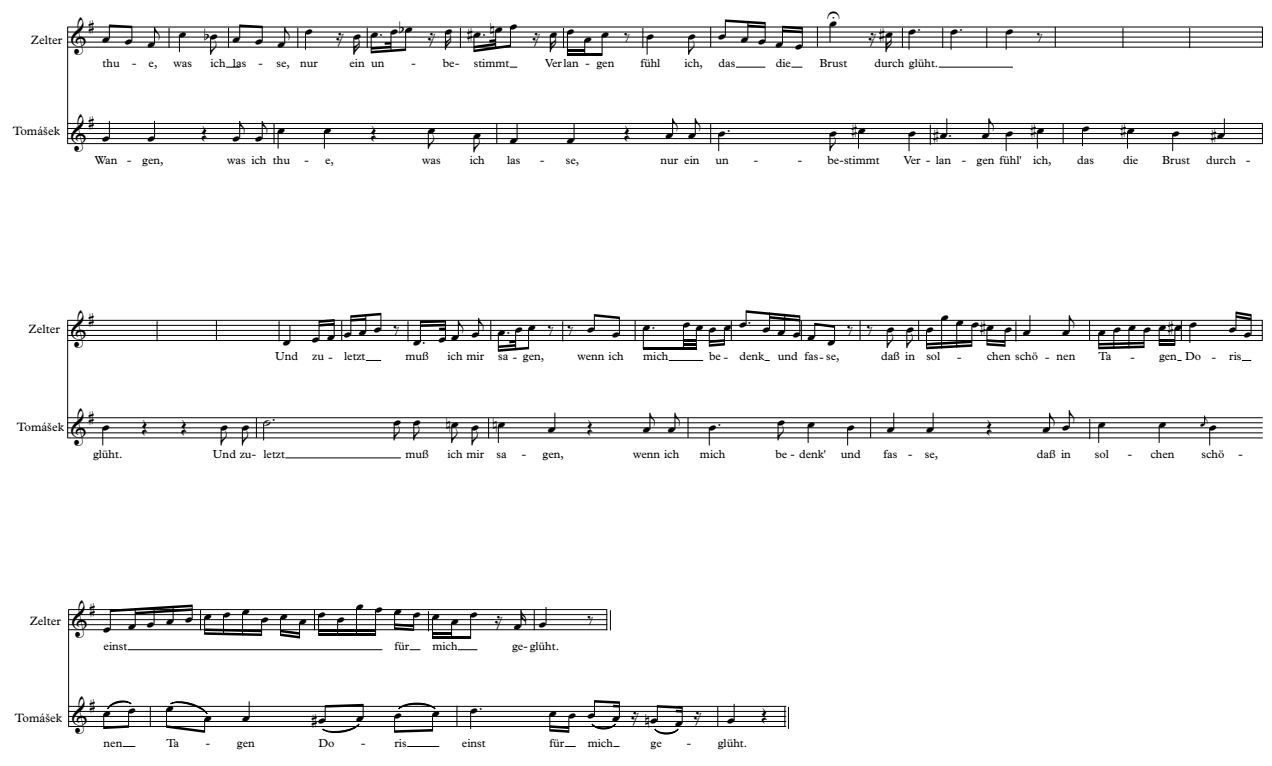

\section{Résumé: Václav Jan Tomášek as a versatile Lieder composer?}

It is important to note that both Zelter and Tomášek employ a complex harmonic pattern and a (partly) through-composed formal design in their settings of Goethe's poem Nachgefühl. While Johanna Kinkel's setting of these words is characterised by harmonic and strophic simplicity, her Lied An den Mond is much more challenging in terms of harmony and pianistic skills than Zelter's and Tomášek's versions of this Lied. Considering the tonal corpus, which centres on the tonic, dominant and rarely-used diminished chords, the supportive function of the piano accompaniment and the modest use of such expressive means as dynamics and arpeggios in Zelter's Lieder, we can conclude that both of Zelter's Lieder examined in this article do not differ from each other in terms of harmonic and expressive complexity or challenge to the pianist. On the contrary, both Kinkel's and Tomášek's settings analysed above are very dissimilar. While Kinkel's setting of An den Mond is fairly complex in relation to the harmonic progression and the piano accompaniment, the harmonic design and piano part in Kinkel's Nachgefühl are very straightforward. On the contrary, Tomášek's setting of An den Mond is less complex than Nachgefühl, although both Lieder deal with similar emotional situations as they both are closely linked with love and loss.

This article has shown that several compositional approaches to the same words may stress different textual aspects of a poem by using varied features of melody, harmony, formal design, expression, and piano accompaniment, an observation which may be ex- 
plained by means of tradition and aesthetic understanding. Possibly more importantly, however, this article has exposed two different compositional approaches to poetry by Václav Jan Tomášek. While Tomášek's version of An den Mond seemed rather conventional in terms of harmony and quite simple in relation to the formal and melodic concepts, his Goethe-Lied Nachgefühl, by employing a more complex harmonic pattern and more diverse melodic turns, throws a different light on Tomášek as a Lieder composer. In his examination of selected Goethe-Lieder of Tomášek's, Kenneth DeLong concludes that:

In his songs as well as in his piano music, Tomášek developed certain musical idioms particular melodic and harmonic patterns, accompanimental figurations, and, most important, specific formal and structural models - which he is content to repeat with slight variations. When there is a happy match between one of his "solutions" and a particular poem [...] the result is an excellent song. When the structure of the poem is less regular or its emotional implications less conventional, Tomášek is markedly less successful. ${ }^{58}$

While DeLong's conclusion led us to insert a question mark behind our title and the characterisation of Václav Jan Tomášek as a versatile Lieder composer, we would now like to make an attempt to reflect on this question (mark) using as a basis the analysis of Tomášek's two Lieder An den Mond and Nachgefühl.

The analysis of these two Lieder demonstrates that Tomášek's style differs from one song to the other in relation to the compositional characteristics mentioned by DeLong. By applying different styles and different levels of complexity, Tomášek includes typical features of both the Gesellschaftslied and the Kunstlied, an observation which was also made by DeLong. ${ }^{59}$ Although DeLong points to the parallels between this historical transition and Tomášek's style, he explains Tomášek's use of musical idioms by means of a missing "quality of imagination ... that finds a fresh musical solution to the setting of each poem, an imagination that can freely go beyond comfortable convention". ${ }^{60}$

In response to DeLong's conclusion and under consideration of our own analysis, we would like to raise two points that might ignite further discussions and might inspire future research. Firstly, it is impossible - and it would be unreasonable - to try to make a definite statement about Tomášek's compositional style on the basis of two songs. Therefore, it would be a desirable goal to undertake a more in-depth investigation of all of Tomášek's Goethe-Lieder in order to establish further differences (and commonalities) between these songs. Such an approach would result in a more representative sketch of Tomášek's compositional style and aesthetic understanding. Additionally, one might also consider Tomášek's settings of other poets in order to find out whether or not Tomášek used certain compositional patterns for particular poets' words. Secondly, this article poses the question whether it was solely a "lack of imagination" which determined

\footnotetext{
58 DeLong, K.: Jan Václav Tomášek’s Goethe Lieder, Kosmas, 1988, iss. 7, p. 82.

59 Ibid., p. 82.

60 Ibid., p. 82.
} 
Tomášek's compositional style. It is widely known that social environments, employment conditions, expectations to the audience and the clientele as well as self-censorship on account of anticipated friends', family members', and acquaintances' preferences may have an influence on a human's (creative) thinking and output. The musicological research canon has only started to take into account theories of publication and cultural studies. Thanks to the increased interest in gender-related issues within the context of historiography, Johanna Kinkel's reception in and her reaction to reviews of the contemporary print media has at least been noted, although it has never been discussed at depth. ${ }^{61}$ However, very little effort has been made to apply within the context of musicology more recent theories originating from the fields of cultural and historical media studies - addressing both female and male composers and musicians.

How much do we know about the aesthetic preferences that ruled Tomášek's social environment? Is it possible that Tomášek (perhaps subconsciously) applied mechanisms of self-censorship on account of his expectations to his audience, his employer, his reviewers, Goethe (whom he met in person), or his musical successors? In other words, do we know whether or not Tomášek's compositional style might have been (partly) influenced by some (unknown or, at least, un-recognised) instance other than his own imagination? In order to find possible answers to these questions, we would like to encourage an exploration of Tomášek's Lieder within the larger context of their personal, historical and compositional-aesthetic background. Not only would such an interdisciplinary approach enrich the research canon being concerned with Václav Jan Tomášek, but it would also contribute to the overall socio-cultural history of the Lied. Tomášek's Lieder, representing the transition from the Classical to the Romantic period by applying stylistic features of both eras, might serve as an excellent - but so far underrated - cornerstone for such a large-scale undertaking.

${ }_{61}$ Monica Klaus (Johanna Kinkel: Romantik und Revolution [Cologne, 2008]) and Hermann Rösch Sondermann ("Johanna Kinkel. Emanzipation und Revolution einer Bonnerin", in Bonn. 54 Kapitel Stadtgeschichte, ed. by Joseph Matzerath [Bonn: Bouvier, 1989], p. 179-188) allude to Kinkel's role as a female composer and musician in their book and article, respectively. 


\title{
Václav Jan Tomášek (1774-1850): A Versatile Lieder Composer? A Comparative Analysis of Selected Goethe Settings by Carl Friedrich Zelter, Václav Jan Tomášek and Johanna Kinkel
}

\begin{abstract}
Carl Friedrich Zelter (1758-1832), Václav Jan Tomášek (1774-1850) and Johanna Kinkel (1810-1858) share at least two commonalities: firstly, they produced a great deal of vocal music, particularly Lieder, so that their compositions influenced the development of the nineteenth-century Lied in one way or the other. Secondly, all three composers set to music Goethe's poems although their (personal) relationships to Goethe differed from each other. Zelter, a very close friend of Goethe's, paid extraordinary attention to the poet's work and its musical potential which is recognisable by means of both the great number of Goethe-Lieder produced by Zelter and the rich musical discussions included in Goethe and Zelter's correspondence. Unlike Zelter, Tomášek met Goethe only a few times and his bequeathed correspondence with Goethe is fairly small. Although Goethe praised Tomášek's settings of his poems on several occasions, Tomášek’s Goethe-Lieder are rather unknown. Johanna Kinkel never met Goethe in person; yet Goethe's poetry takes a significant place within her Lieder Euvre. Especially her early Lieder compositions, which were published in 1838 and 1839 and which include four Goethe settings, were received with great enthusiasm by the contemporary musical print media.

By means of comparative analysis, this article aims to shed light on a selection of Zelter's, Tomášek's and Kinkel's Goethe settings. As a transitional musical character between the Classical and the Romantic periods, Václav Jan Tomášek applied compositional features originating from both eras and his compositions thereby serve as a link between the rather Classically-oriented composer Zelter and Kinkel whose compositional style reflects typical Romantic features. Using as an analytical basis the two Goethe-Lieder An den Mond and Nachgefühl, this article depicts differences and similarities between all three composers' compositional styles as well as between the two Lieder of each individual composer. The aim of this article is to place Tomášek's compositional versatility within its own context and, as a result, to suggest possible directions for future examinations of Tomášek’s (and other composers') (Goethe)-Lieder.
\end{abstract}




\title{
Václav Jan Tomášek (1774-1850): Všestranný písňový skladatel? Komparativní analýza vybraných hudebních zpracování Goethových básní od Carla Friedricha Zeltera, Václava Jana Tomáška and Johanny Kinkelové
}

\begin{abstract}
Abstrakt
Carl Friedrich Zelter (1758-1832), Václav Jan Tomášek (1774-1850) a Johanna Kinkelová (1810-1858) se shodují nejméně ve dvou skutečnostech: zkomponovali velké množství vokální hudby, zvláště písní, jež určitým způsobem ovlivnily vývoj písně 19. století. Tito tři skladatelé taktéž zhudebnili Goethovy básně, ačkoliv se jejich (osobní) vztah ke Goethemu od sebe lišil. Zelter, Goethův velmi blízky přitel, věnoval mimořádnou pozornost básníkovu dílu a jeho hudebnímu potenciálu, což je zřejmé z velkého množství zhudebněných Goethových básní právě Zelterem a hojností hudebních diskusí reflektovaných v korespondenci obou umělců. Tomášek se na rozdíl od Zeltera setkal s Goethem jen párkrát a jejich vzájemná dochovaná korespondence je poměrně skromná. I když se Goethe několikrát pochvalně vyjádřil o Tomáškově zhudebnění jeho básní, Tomáškovy písně na Goethovy náměty jsou spíše neznámé. Johanna Kinkelová se s Goethem nikdy nesetkala; nicméně Goethova poezie zabírá význačné místo v její písňové tvorbě. Zvláště její rané písně, publikovány v letech 1838 a 1839, zahrnující čtyři zhudebnění Goethových básní, byly dobovým hudebním tiskem přijaty s velkým entusiasmem.

Prostřednictvím srovnávacích analytických metod si tato studie dala za cíl osvětlit vybrané písně na Goethovy texty zkomponované Zelterem, Tomáškem a Kinkelovou. Václav Jan Tomášek, jehož tvorbu můžeme považovat za přechod mezi hudebním klasicismem a romantismem, užival kompoziční prvky obou období, a proto slouží jako ideální propojení mezi spíše klasicky orientovaným Zelterem a Kinkelovou, jejíž kompoziční styl obsahuje typicky romantické rysy. Na podkladě analýzy dvou zhudebněných Goethových básní An den Mond a Nachgefühl tato studie zobrazuje odlišnosti a podobnosti mezi těmito třemi skladatelskými kompozičními styly, stejně jako mezi dvěma písněmi každého ze skladatelů. Cílem tohoto článku je naznačit Tomáškovu kompoziční mnohostrannost a navrhnout možné směry budoucího výzkumu Tomáškových písní (na Goethovy texty), ale i písní dalších skladatelů.
\end{abstract}




\section{Key Words}

Nineteenth-Century; lied; J. W. Goethe; J. V. Tomášek; comparative analysis.

\section{Klíčová slova}

19. století; píseň; J. W. Goethe; J. V. Tomášek; komparativní analýza. 